\title{
Phenotype, genotype of neonatal diabetes mellitus due to insulin gene mutation
}

\author{
Can Thi Bich Ngoc ${ }^{1 *}$, Vu Chi Dung ${ }^{1}$, Bui Phuong Thao ${ }^{1}$, Nguyen Ngoc Khanh ${ }^{1}$, Nguyen Phu Dat ${ }^{2}$, Maria $_{\text {Craig }}{ }^{3}$, \\ Sian Ellard ${ }^{4}$, Nguyen Thi Hoan ${ }^{1}$
}

From 8th APPES Biennial Scientific Meeting

Darwin, Australia. 29 October - 1 November 2014

Insulin (INS) gene mutations that cause permanent neonatal diabetes mellitus change single protein building blocks (amino acids) in the protein sequence. These mutations are believed to disrupt the cleavage of the proinsulin chain or the binding of the $A$ and $B$ chains to form insulin, leading to impaired blood sugar control. At least 10 mutations in the INS gene have been identified in people with permanent neonatal diabetes mellitus.

\section{Objective}

To describe clinical features and laboratory manifestations of patients with INS gene mutation and to evaluate outcome of management.

\section{Subject and methods}

Clinical features, biochemical finding, mutation analysis and management outcome of 3 cases from 3 unrelated families were studied. All exons of INS gene were amplified from genomic DNA and directly sequenced.

\section{Results}

3 cases (one girl and two boys) onset at $126.6 \pm 56.7$ days of age with gestation age of $38.0 \pm 1.4$ weeks, birth weight of $2850 \pm 494.9 \mathrm{~g}$. All of them admitted with the feature of diabetic ketoacidosis with $\mathrm{pH}$ of $6.94 \pm 0.16$; $\mathrm{HCO}_{3}^{-} 2.63 \pm 0.85 \mathrm{mmol} / \mathrm{l} ; \mathrm{BE} 26.05 \pm 4.03 \mathrm{mmol} / \mathrm{l}$, plasma glucose levels were $37.57 \pm 15.2 \mathrm{mmol} / \mathrm{l}, \mathrm{HbA1C}$ of $9.9 \pm 2.5 \%$. Mutation analysis of the INS gene showed: heterozygous for a novel missense mutation (c.127T >A; $\mathrm{C} 43 \mathrm{~S}$ ) in exon 2 of INS gene in one case; heterozygous for a novel INS splicing mutation, c.188-31G>A of the INS gene in two cases. After 8 months of insulin treatment, two patients with c.188-31G $>$ A mutation have

Department of Endocrinology, Metabolism and Genetics. Vietnam National Hospital of Paediatrics, Hanoi, Vietnam

Full list of author information is available at the end of the article normal development with DQ $80-100 \%$, HbA1C of 6.85 $\pm 0.49 \%$, quite normal blood glucose levels. The case with c.127T $>$ A mutation treated with insulin for 8 years has physical development delay, poor blood glucose control with $\mathrm{HbA} 1 \mathrm{C}$ of $11.4 \%$.

\section{Conclusions}

It is important to perform screening gene mutation for patients with diabetes diagnosed before 6 months of age to control blood glucose and follow up the patients.

\section{Authors' details \\ Department of Endocrinology, Metabolism and Genetics. Vietnam National Hospital of Paediatrics, Hanoi, Vietnam. ${ }^{2}$ Hanoi Medical University, Hanoi, Vietnam. ${ }^{3}$ The Children Hospital at Westmead, Sydney, NSW, Australia. ${ }^{4}$ Molecular Genetics, Old Path Lab, Royal Devon \& Exeter Hospital, Barrack Road, Exeter, UK.}

Published: 28 April 2015

doi:10.1186/1687-9856-2015-S1-P12

Cite this article as: $\mathrm{Ngoc}$ et al:: Phenotype, genotype of neonatal diabetes mellitus due to insulin gene mutation. International Journal of Pediatric Endocrinology 2015 2015(Suppl 1):P12.

Submit your next manuscript to BioMed Central and take full advantage of:

- Convenient online submission

- Thorough peer review

- No space constraints or color figure charges

- Immediate publication on acceptance

- Inclusion in PubMed, CAS, Scopus and Google Scholar

- Research which is freely available for redistribution 